\title{
Did massive glacial dewatering modify sedimentary structures on the Amundsen Sea Embayment shelf, West Antarctica?
}

\author{
Estella Weigelt ${ }^{\mathrm{a}, *}$, Gabriele Uenzelmann-Neben ${ }^{\mathrm{a}}$, Karsten Gohl ${ }^{\mathrm{a}}$, Robert D. Larter ${ }^{\mathrm{b}}$ \\ a Alfred Wegener Institute for Polar and Marine Research, Postfach 120161, 27515 Bremerhaven, Germany \\ ${ }^{\mathrm{b}}$ British Antarctic Survey, High Cross, Madingley Rd, Cambridge CB3 OET, UK
}

\section{A R T I C L E I N F O}

Article history:

Received 9 November 2011

Accepted 17 April 2012

Available online 25 April 2012

Keywords:

West Antarctic Ice Sheet

Amundsen Sea

seismic reflection

reflection-poor

dewatering

mud-diapir

\begin{abstract}
A B S T R A C T
Multichannel seismic reflection lines collected in the western Amundsen Sea Embayment (ASE) provide an insight into the sedimentary cover on the shelf, which documents glacial processes. Numerous columnar, reflection-poor structures penetrating the sedimentary sequences on the middle shelf form the focus of this study. The features range between 50 and $500 \mathrm{~m}$ in width, and from a few metres up to $500 \mathrm{~m}$ in height. The columns originate and end at different depths, but do not seem to penetrate to the seafloor. They show well-defined vertical boundaries, and reflection signals can be identified below them. Hence, we exclude gasbearing chimneys. Based on the general seismic reflection characteristics we suggest that the columns originate from dewatering processes which occur close to glaciated areas where fluids are pressed out of rapidly loaded sediments. Likely several mud-diapirs rise from water-rich mud layers within a mixed sedimentary succession and penetrate overlying denser and coarse-grained sediment strata. The presence of fluidescape veins indicates a glacial origin and overprinting of the older sedimentary sequences on the ASE. The locations of the structures indicate that grounded ice sheets reached at least onto the middle shelf during former glacial periods.
\end{abstract}

(c) 2012 Elsevier B.V. All rights reserved.

\section{Introduction}

Sediments of glaciated continental shelves document various stages and processes of glacial dynamics. The West Antarctic Ice Sheet (WAIS) changed dramatically in its volume since the Last Glacial Maximum (LGM). So the Pine Island and Thwaites Glacier systems, the two largest ice-streams draining into Pine Island Bay in the eastern Amundsen Sea Embayment (ASE), have shown striking thinning during the last two decades (e.g. Vaughan et al., 2001; Rignot and Jacobs, 2002; Shepherd et al., 2004; Pritchard et al., 2009). Most of the reconstructions of the WAIS dynamics for the ASE have concentrated on the late Quaternary (e.g. Lowe and Anderson, 2002; Evans et al., 2006; UenzelmannNeben et al., 2007; Graham et al., 2010), or are restricted to the continental slope and deep sea (e.g. Nitsche et al., 2000; Scheuer et al., 2006). There are still few studies on older ice sheet dynamics on the shelf area (e.g. Weigelt et al., 2009). Seismic data from the shelf of the ASE in West Antarctica reveal previously unexplained zones of chimney or block-like features that are seismically transparent and have unique geometries. These features, which we assume to be of relevance to processes close to glaciated shelves, provide an opportunity to gain insight into sediment to ice-sheet interactions in general and during the Neogene development of WAIS in particular.

\footnotetext{
* Corresponding author. Tel.: + 4947148311885.

E-mail address: estella.weigelt@awi.de (E. Weigelt).
}

We study the structure and characteristics of the observed chimney or block-like seismically transparent zones in the sedimentary column and discuss their cause and significance.

\section{Regional setting}

In common with other shelf areas of Antarctica, the shelf of the ASE deepens inshore (Fig. 1), mainly due to cumulative glacial erosion, but with an additional component due to lithospheric flexure caused by the load of the modern WAIS (e.g. ten Brink et al., 1995; Anderson, 1999). Pronounced glacial troughs incise the inner continental shelf down to 1000-1600 $\mathrm{m}$ water depths in their deepest parts (Nitsche et al., 2007; Larter et al., 2009). These troughs converge towards the middle shelf (Graham et al., 2010) and extend across the outer shelf, which has a mean water depth of 500-600 m, with greatly reduced relief (Lowe and Anderson, 2002; Nitsche et al., 2007).

The timing of the onset of glaciation in coastal West Antarctica is poorly constrained. Larter (2008) summarized that a regular supply of both glacially derived terrigenous sediments and interglacial biogenic sediments has reached the continental rise of the Antarctic Peninsula since at least the Middle Miocene. The first major glacial advances to the Ross Sea shelf have been dated as Oligocene (e.g. Bartek et al., 1991; De Santis et al., 1995) but with major expansion to the shelf edges not before the mid-Miocene (Bart, 2003). Glacial advances onto the outer shelf of the Amundsen Sea Embayment are evident from observed prograding sequences (Nitsche et al., 2000) 


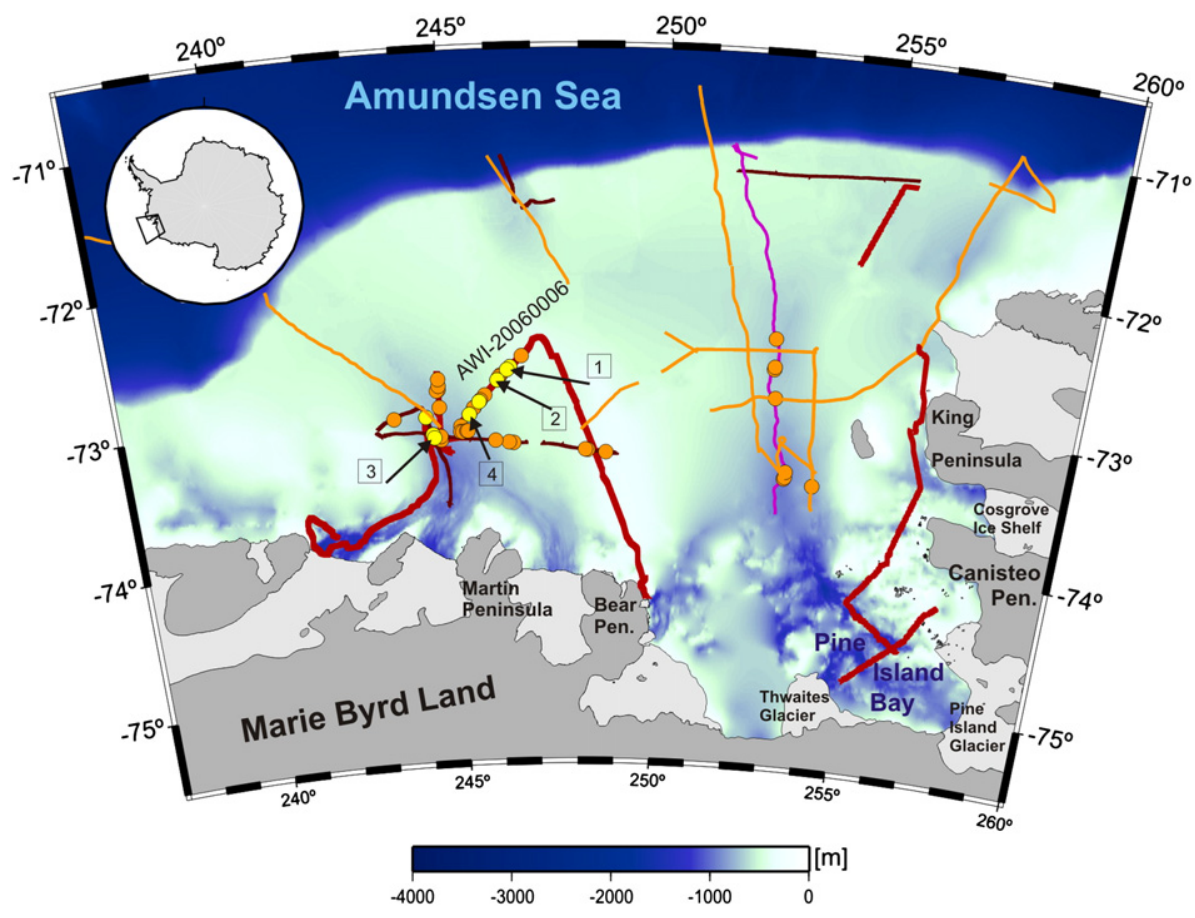

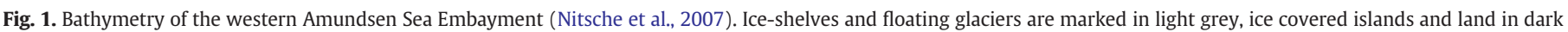

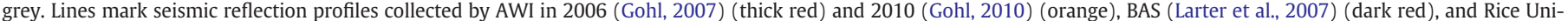

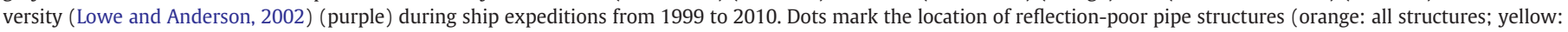
very well-defined structures). Framed numbers show the location of selected structures discussed in the text.

but ages are unconstrained because no scientific drilling has taken place in this area. Weigelt et al. (2009) described alternating sequences of reflection-poor units and closely spaced reflector sequences, which they related to a repeated advance and retreat of ice sheets at least onto the middle shelf. They inferred from a comparison of the seismic stratigraphy of the ASE to lithology and borehole records of the Ross Sea that the sedimentary sequences were deposited since Miocene times. However, a detailed age control without drilling data is too speculative. For late Quaternary times the development of an extended ice sheet in the ASE is better constrained. Evans et al. (2006) proposed that the WAIS reached the shelf edge and was drained by at least one palaeo-ice stream during the (LGM). Afterwards, the ice sheet retreated in phases, with the most rapid recession occurring between 16 and 12 kyr (Lowe and Anderson, 2002; Smith et al., 2011). Over the last decades the two largest ice-streams that drain into Pine Island Bay, Pine Island Glacier (PIG) and Thwaites Glacier (Fig. 1) have shown dramatical thinning (e.g. Vaughan et al., 2001; Rignot and Jacobs, 2002; Rignot, 2008; Pritchard et al., 2009). Especially the PIG reveals thinning and rapid basal melting combined with grounding line retreat (Jenkins, et al., 2010; Jakobsson et al., 2011) as well as a marked flow acceleration (Scott et al., 2009).

\section{Material and methods}

This study used a set of multi-channel seismic (MCS) reflection lines acquired from the western ASE during RV Polarstern cruise ANT-XXIII/4 (Gohl, 2007; Uenzelmann-Neben et al., 2007; Weigelt et al., 2009) and cruise ANT-XXVI/3 (Gohl, 2010) (Fig. 1). Seismic sources consisted of three GI-guns ${ }^{\mathrm{TM}}$ with a total generator volume of 2.21 generating frequencies up to $250 \mathrm{~Hz}$. Seismic reflections can be identified at frequencies up to $100 \mathrm{~Hz}$, which implies a vertical resolution in soft sediments of about $8 \mathrm{~m}$. Shots were fired every $12 \mathrm{~s}$ corresponding to a distance of $31 \mathrm{~m}$. The data were recorded with a 96-channel or a 240 -channel streamer $(600 \mathrm{~m}$, or $3000 \mathrm{~m}$ active length respectively) at a sample rate of $1 \mathrm{~ms}$. The seismic data processing comprised sorting ( $25 \mathrm{~m}$ CDP interval), and a detailed velocity analysis (every $50 \mathrm{CDP}, \sim 1.2 \mathrm{~km}$ ), which enabled a successful suppression of seabed multiples. Noise was successfully suppressed via a Karhunen-Loeve filter (Yilmaz, 2001). Before stacking the traces were filtered with a bandpass of 5 to $200 \mathrm{~Hz}$, but no further gain was applied. Finally, the data were migrated with a finite-difference time migration. For display, a bandpass between 10 and $110 \mathrm{~Hz}$ was performed.

Together with the multi-channel seismic lines, high-resolution sub-bottom profiler data with $18 \mathrm{kHz}$ primary frequency and secondary frequencies of $2.5-5.5 \mathrm{kHz}$ were recorded with the PARASOUND echo-sounder system. We incorporated these records in this study to provide supplementary information about the uppermost sedimentary layers on a scale of metres. For these PARASOUND records conversion from two-way traveltime (twt) to depth was made using $\mathrm{v}_{\mathrm{p}} \sim 1500 \mathrm{~m} / \mathrm{s}$.

Additionally single-channel seismic lines collected on cruises JR141 of the RRS James Clark Ross (Larter et al., 2007) and NBP 99/02 of the R/V N.B. Palmer (Lowe and Anderson, 2002) (Fig. 1) were used.

\section{Results}

An examination of reflection seismic data of the ASE revealed a large number of columnar reflection-poor structures penetrating the sedimentary units (Fig. 2). Within these features we observe a strong reduction in reflection amplitude. Laterally, the structures have welldefined vertical flanks (Fig. 3). The height of the structures ranges between tens of metres and about $500 \mathrm{~m}$, and the width between 50 and $500 \mathrm{~m}$. The width does not change with depth within an individual structure. The column depths and dimensions were calculated using interval velocities derived from stacking velocities of the corresponding normal-moveout corrections. Due to the short streamer length $(800 \mathrm{~m}$ in total) however, this method is too inaccurate to 

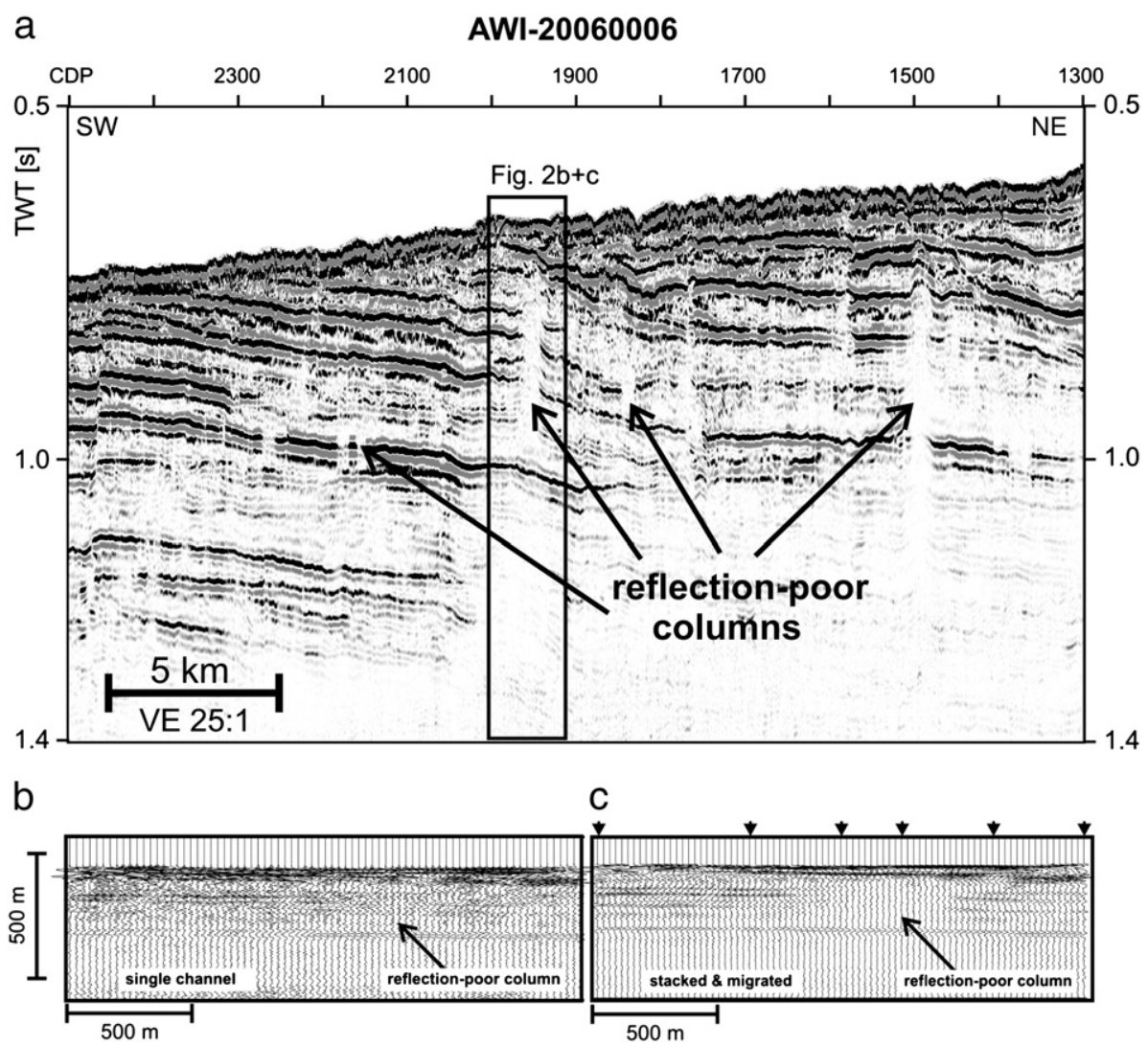

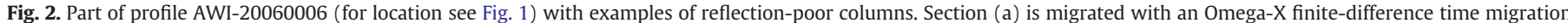

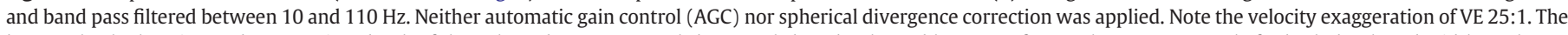

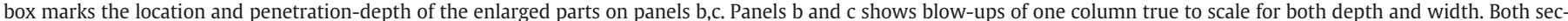

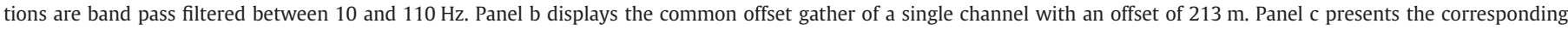
stacked and migrated part. Black arrows in panel c mark the CDPs selected for velocity analysis.

resolve any differences in $\mathrm{v}_{\mathrm{p}}$ between the columns and surrounding sediments.

The occurrence of these reflection-poor features is not restricted to one particular sedimentary unit. They occur in the whole sedimentary sequence, and start and end in different depths (Fig. 2). The top reflection of the columns is dome-shaped (Fig. 3). A few features rise to the sea floor but neither the seismic sections nor the sub-bottom profiler data indicate an escape of material (Fig. 4). Most of the columns are covered by at least $50 \mathrm{~ms}$ twt $(\sim 40 \mathrm{~m})$ of sediment, which exhibits strong acoustic layering. Below most of the columns we observe continuous reflections (Fig. 3). The internal reflection amplitudes within the columns are attenuated but can still be traced. The internal reflections are gently

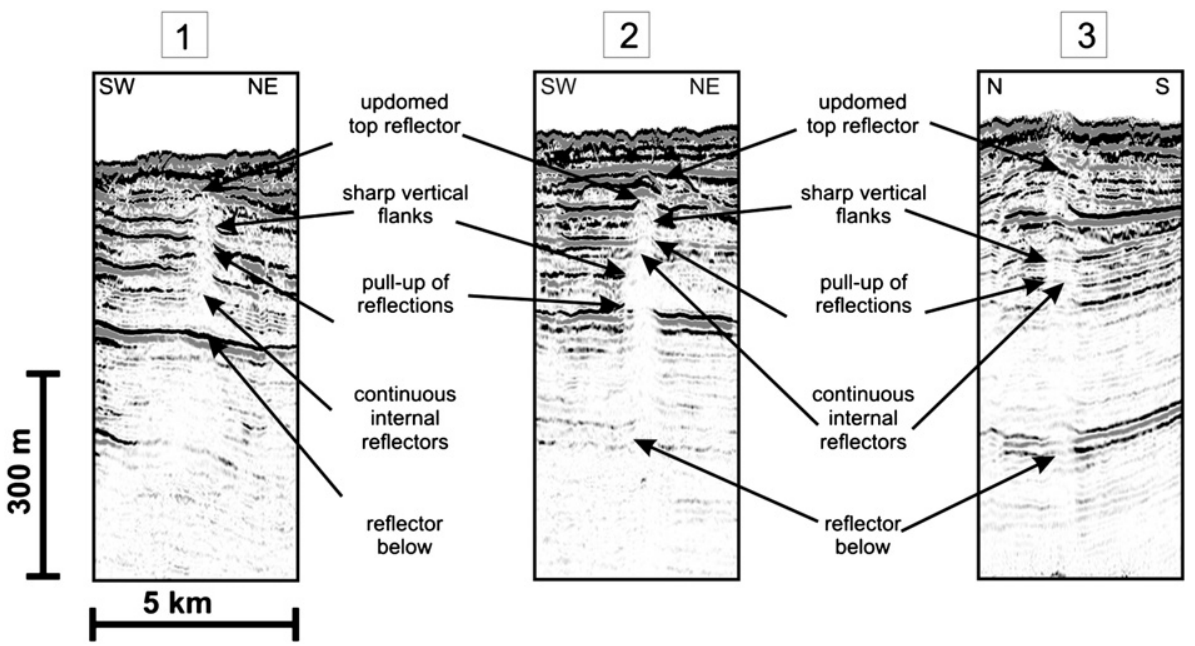

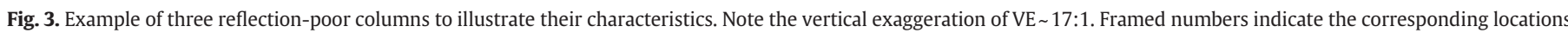
in Fig. 1. 
a

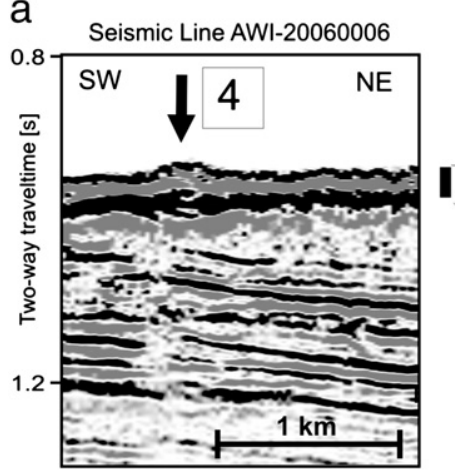

b

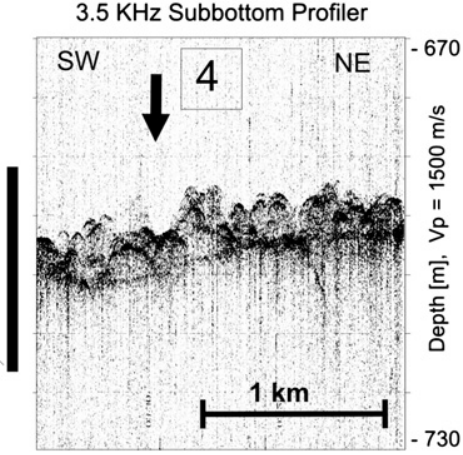

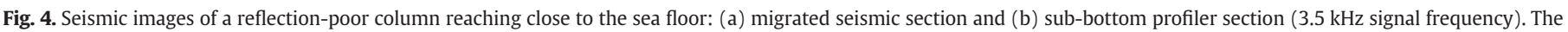

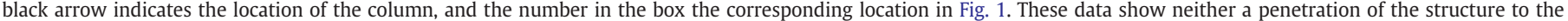
seafloor nor any evidence for an escape of fluids.

arched. At the flanks of the structures we observe upward-deformed reflections (Fig. 3). We found no evidence that the reflection-poor features are not connected to faults.

By studying common-offset gathers for single channels of our MCS data, we excluded the possibility of the columns being artifacts of incorrect NMO corrections. These data also show weak identifiable evidence for reflection-poor zones (Fig. $2 b$ ). We also exclude that the reflectors visible below the structures are imaged by large offset ray paths. Most columns were recorded by the short streamer system whose maximum offset was $770 \mathrm{~m}$. Fig. $2 \mathrm{~b}$ displays the gather for a channel with only $213 \mathrm{~m}$ offset, still deeper reflections can be identified.

In mapping the reflection-poor columns, we find that they occur on the middle shelf area of the ASE (Fig. 1). Most of the structures are located between the bathymetric high that extends NNW from Bear Peninsula and the sediment filled part of the troughs converging north of Martin Peninsula. No indications for reflection-poor zones are found on the inner shelf where sediments were deposited only in pockets or as thin drape.

\section{Discussion}

We observe numerous reflection-poor columnar features, which we exclude for the following reasons to present acquisition or processing artefacts. Firstly, the structures are well identified on both single- and multi-channel seismic data. Secondly, closely picked velocity-depth pairs showed that the flanks of the columns are independent from the locations of the NMO corrections. The structures also remain in tests with crude velocity models.

We consider different possible origins for the columns, which will be discussed below: gas hydrates, free gas, mud volcanoes, diagenetic related horizons, dykes, carbonate mounds, buried ice scours, and dewatering veins (Table 1 ).

\subsection{Gas hydrate related bottom-simulating reflectors}

Bottom simulating reflectors beneath gas hydrate stability zones are mostly related to the presence of free gas trapped beneath solid methane/ethane clathrates (e.g. Shipley et al., 1979). These gas hydrates are stable under very limited pressure and temperatures conditions that are found beneath and parallel to the seafloor topography (Sloan, 1998). Beneath the gas-hydrate stability zone, evidence of free gas can often be observed (e.g. Petersen et al., 2007). The velocity contrast between the hydrate and the free gas-bearing underlying sediment causes a highly reflective horizon with reversed polarity (Pecher et al., 1996; Berndt et al., 2004). This reflector is oriented parallel to the seafloor and hence called a Bottom-Simulating Reflector (BSR). Due to the negative acoustic impedance contrast (gas hydrate/free gas) the BSR shows an inverse polarity (Fig. 5a).
The presence of gas hydrates has been inferred on some parts of the Antarctic continental margin, mainly based on the observation of a BSR on seismic records (e.g. Kvenvolden et al., 1987; Geletti and Busetti, 2011), or on geochemical records of methane and chloride content (Mann and Gieskes, 1975; McIver, 1975).

As shown in Fig. 2a, neither the top nor the base reflection of the reflection-poor structures follows the seafloor topography and neither do they show an inverse polarity (Fig. 2b). Thus, no BSRs are observed. We thus rule out gas hydrates as a possible origin of the reflection-poor zones.

\subsection{Free gas/oil}

The appearance of free gas in deep-sea basins can be explained either by the dissociation of gas hydrates (e.g. Sain et al., 2000) or associated with oil. We already excluded biogenic gas as a source for the observed reflection-poor zones, so we focus on the occurrence of thermogenic gas and oil. Oil is preserved in reservoir rock if it is trapped, either structurally

Table 1

Possible origins for reflection-poor columns. The seismic characteristics observed in this study are classified into aspects for or against the suggested origins.

\begin{tabular}{|c|c|c|}
\hline Origin & Pro & Contra \\
\hline Gas hydrates & - Reflectors below & $\begin{array}{l}\text { - No BSR } \\
\text { - No gas indication at surface } \\
\text { - Upward trending flanks } \\
\text { - Repeated glacial erosion }\end{array}$ \\
\hline Free gas & - Reflection-poor structure & $\begin{array}{l}\text { - Reflectors below } \\
\text { - Sharp vertical flanks } \\
\text { - No gas indication at surface }\end{array}$ \\
\hline $\begin{array}{l}\text { Gas-related mud } \\
\text { volcanoes }\end{array}$ & $\begin{array}{l}\text { - Reflection-poor structure } \\
\text { - Upward trending flanks } \\
\text { - Reflectors below }\end{array}$ & - Internal reflectors \\
\hline Diagenetic horizon & - Reflectors below & - Weak internal reflections \\
\hline Dykes & $\begin{array}{l}\text { - Reflection-poor structure } \\
\text { - Updomed cover reflectors } \\
\text { - Upward trending flanks }\end{array}$ & $\begin{array}{l}\text { - No sills } \\
\text { - Internal reflectors } \\
\text { - Sediments below }\end{array}$ \\
\hline Carbonate mounds & $\begin{array}{l}\text { - Reflection-poor structure } \\
\text { - Reflectors below } \\
\text { - Sharp vertical flanks } \\
\text { - Updomed top reflectors }\end{array}$ & $\begin{array}{l}\text { - Repeated glacial erosion } \\
\text { - Internal reflectors }\end{array}$ \\
\hline Buried ice scours & $\begin{array}{l}\text { - Reflection-poor structure } \\
\text { - Reflectors below } \\
\text { - Sharp vertical flanks }\end{array}$ & $\begin{array}{l}\text { - Updomed cover reflectors } \\
\text { - Constant width } \\
\text { - Upward trending flanks } \\
\text { - Internal reflectors }\end{array}$ \\
\hline Dewatering veins & $\begin{array}{l}\text { - Reflection-poor structure } \\
\text { - Reflectors below } \\
\text { - Sharp vertical flanks } \\
\text { - Updomed cover reflectors } \\
\text { - Upward trending flanks } \\
\text { - Internal reflectors }\end{array}$ & \\
\hline
\end{tabular}


a

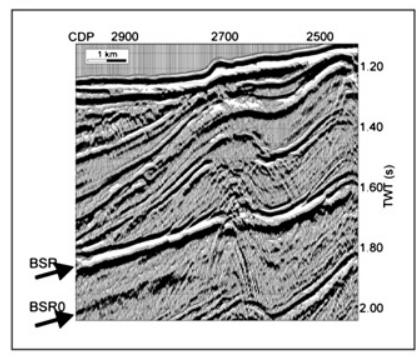

b

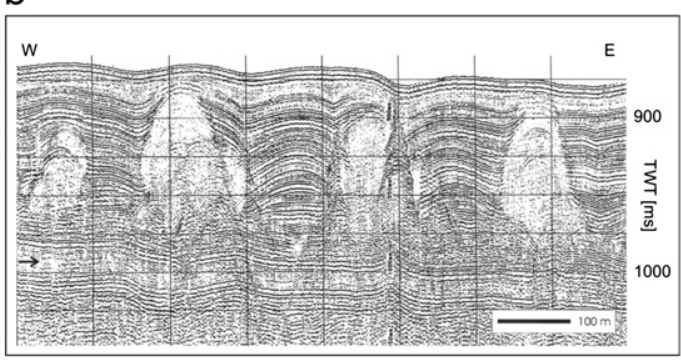

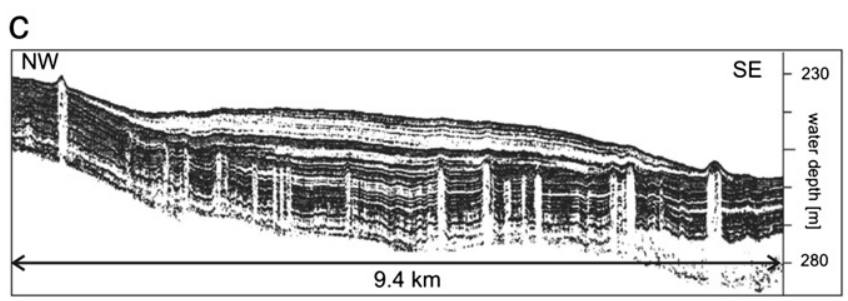

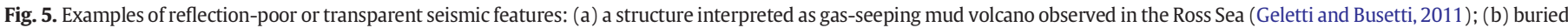

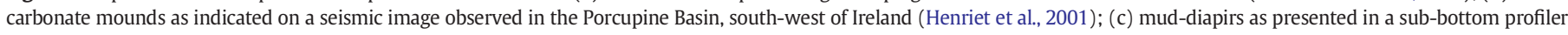
section of the central Vilkitsky Strait (Kleiber et al., 2001).

or stratigraphically or both. If a reservoir rock is not totally sealed, the upward migrating oil (and associated gas) produces chimneys or pockmarks that can be clearly observed on seismic profiles (Tingdahl et al., 2001; Gay et al., 2006). Due to the slight impedance contrast between oil bearing and water bearing sediments (oil-water contact), a phase displacement at the transition from weak to strong reflections occurs.

We do not observe any structural traps within sedimentary layers studied in the ASE. We are aware that stratigraphical traps are sometimes difficult to identify, but neither the seismic sections nor the sub-bottom profiler data indicate structures of pockmarks or chimneys at any location above the reflection-poor zones, thus their occurrence seems unlikely. Additionally, we do not observe any phase displacement within the top reflection of the columns as an indication for an oil water contact, which excludes oil as the origin of the reflection-poor chimneys.

\subsection{Gas-related mud volcanoes}

Gas-related mud volcanoes originate from the upwelling of gaseous mud from depth (e.g. Neurauter and Bryant, 1990; Sager et al., 2003). Faults provide escape pathways for the fluid and gas pressure built up within zones of overpressure. The released gas and fluids entrain sediments to form a slurry of under-consolidated mud, which migrates towards the sea floor. Mud volcanoes are seismically transparent or chaotic and strong reflections occur directly underneath (Neurauter and Bryant, 1990; Sager et al., 2003). An upward-deformation of reflectors at the flanks can sometimes be observed. The features are circular to elliptical in shape and several $100 \mathrm{~s}$ of metres in width and a few to 10 s of metres in height. The reflection-poor zones observed by us show the same sizes as the ones interpreted as mud volcanoes in the Ross Sea (Fig. 5a) (Geletti and Busetti, 2011). Still, the seismic image in the reflection-poor zones in the ASE is slightly different with only attenuated reflection amplitudes but no chaotic character. Furthermore, we already ruled out the existence of gas in the ASE. Fluid release, on the other hand, can be considered as a possible mechanism for generating the reflection-poor columns, as will be shown later (Dewatering veins and Water-Escape Features).

\subsection{Diagenetically related reflections}

Similar to gas hydrate related reflections, diagenetically caused reflections are sub-horizontally oriented and often crosscut the seismic reflection stratigraphy. A diagenetic related reflection consists of either opal or porcellanite bearing horizons. The origin of such reflections is biogenic and amorphous opal A, which consists of mostly unicellular siliceous micro-organisms, such as diatoms or radiolarians. At temperatures between $30^{\circ} \mathrm{C}$ and $50{ }^{\circ} \mathrm{C}$ opal A converts to cristobalite (opal CT) (Tribble et al., 1992) and later to quartz (Kastner et al., 1977). Due to this diagenesis, the seismic velocity increases and creates a positive acoustic impedance contrast (Volpi et al., 2003; Berndt et al., 2004). During transition bound water is expelled and mobilised under pressure but also pressurizes the unit due to volume expansion (Moss and Cartwright, 2010). This phenomenon leads to the formation of pillar structures, which have been observed seismically in the North Sea (Moss and Cartwright, 2010). The opal A/CT phase boundary depends solely on temperature and time but not on pressure (Grützner and Mienert, 1999). The corresponding acoustic impedance boundary therefore sometimes mimics the seafloor less closely than a gas hydrate BSR. Sediments beneath the opal A/CT conversion contain opal CT bearing layers, thus reflections beneath the opal $\mathrm{A} / \mathrm{CT}$ reflections appear in higher amplitude than horizons above (Berndt et al., 2004). Porcellanite is a diagenetic rock also known as chert, resulting from the opal A to opal CT conversion (Jones and Segnit, 1971; Riech and Von Rad, 1979). Porcellanites are mostly documented from Tertiary Southern Hemisphere sediments, restricted to local areas (Bohrmann, et al., 1990).

On all our seismic sections, the tops of the reflection-poor zones show positive polarity, indicating a downward increase in acoustic impedance, and they do not mimic the seafloor (Figs. 2 and 3). Contrary to the attributes of opal A/CT BSRs and porcellanites, this reflection is in higher amplitude than the underlying reflectors and does not crosscut other reflections but conforms to the surrounding stratigraphy. Thus, an opal A/CT phase boundary appears unlikely as the origin of the observed reflection-poor features.

\subsection{Dykes}

Intrusions of igneous material into sedimentary basin infills can be horizontal ( sills) or vertical (dykes). Dykes need a submarine magma chamber as a source (Lee et al., 2006). Due to the acoustic impedance contrast between sedimentary layers and intrusive material, dykes are characterised by a narrow, seismically transparent or low signalto-noise zone with a high amplitude, positive top reflection. Furthermore, dykes commonly show upward-deformed flanks and often crosscut the surrounding strata (Lee et al., 2006). They extend from 
deeper high-amplitude reflections to their top reflections and may form conduits for either magmatic material or fluids (Lee et al., 2006). Adjacent Marie Byrd Land in West Antarctica has experienced volcanism since the mid-Neogene, thus a magmatic origin of the columns might seem plausible. However, dykes have a homogeneous appearance with hardly any internal reflections. In contrast, we observe weak, but continuous reflectors throughout the reflectionpoor zones. Furthermore, magmatic intrusions would generate horizontal sills or basaltic floods with a large acoustic impedance contrast at their boundary to the surrounding sediments. We do not observe such sills. Additionally, magmatic intrusions would rise from the basement and penetrate the sedimentary sequences. In contrast, we observe horizontal and undisturbed reflectors throughout the sedimentary units below the reflection-poor features (Fig. 3). As a result, these columns are unlikely to represent volcanic dykes.

\subsection{Carbonate mounds}

Carbonate mounds are accumulations of epibenthic communities that occur in localized clusters. They vary in size (up to hundreds of metres in width and height) and shape, being conical, ridged and ring shaped and sometimes have very steep sides (Hovland et al., 1994). Carbonate mounds show a chaotic seismic signature and commonly exhibit up-doming of subsurface parallel reflectors below the mounds (Hovland et al., 1994). This up-doming is a velocity effect resulting from a higher $\mathrm{v}_{\mathrm{p}}$ in the carbonate mound. Fig. $5 \mathrm{~b}$ shows a seismic reflection example of buried carbonate mounds in the Porcupine Basin west off Ireland (Henriet et al., 2001). These balloonshaped reflection-poor features are embedded in horizontal reflector sequences up to their flanks and are covered by a convex sediment drape. Below these mounds undisturbed horizons are visible (Henriet et al., 2001).

Evidence for coral communities in Antarctic waters were found on sea-floor videos by Post et al. (2010) on the upper continental slope off George V Land. The authors suggested that their location is controlled by the depth of maximum iceberg scouring, food-supply by organicrich bottom water, and land derived substrates.

The reflection poor columns observed in the ASE show similar seismic characteristics as described for the examples of carbonate mounds above, i.e. the steep flanks, the updomed sedimentary cover, and an identifiable base reflector would be indications for the presence of carbonate mounds. As precondition for carbonates the sedimentary sequences on the shelf of the ASE would have to be formed below the depth of grounded ice. But in contrast there is evidence that the deposits were repeatedly overprinted by the advance and retreat of grounding ice sheets which reached at least onto the middle shelf area in the past (Weigelt et al., 2009). Only if the tops of the mounds were buried by a thick layer of interglacial sediments a subsequent advance would not disturb them. Otherwise, the formerly constructed carbonate mounds would have been eroded, and sediments accumulated later on them should be indicated by flat-lying reflectors. But for the most reflection-poor structures we observe updomed tops, upwards deformed slopes, and continuing reflections throughout the blocks. These properties we think rather indicate a post-erosional process.

\subsection{Buried glacio-morphological structures}

Glacio-morphological features such as iceberg scours, mega-scale glacial lineations and grounding zone wedges characterise most glaciated shelves (e.g. Stoker, 1997; Dowdeswell et al., 1997). Buried scours have been cut into the sea bed by grounded ice-sheets or grounded icebergs calved from ice shelves and tidewater glaciers, and refilled later with glacially derived or marine material. Examples are described for the North Sea and mid-Norwegian Shelf (Long and Praeg, and references therein, 1997). They show that buried ice scours can reach some $100-200 \mathrm{~m}$ in width but only a few metres in relief. In our case the much higher relief of several $100 \mathrm{~s}$ of metres would require massively extended and grounded ice-sheets deeply cutting into the sea bed. Such incisions should be $\mathrm{V}$ or U-shaped as shown by recent scours (e.g. Kuijpers et al., 2007; Graham et al., 2009), whereas the reflection-poor zones observed in the ASE show a constant width throughout their whole height. We further observe local deformation of reflections at the column's flanks, which cannot be explained by the impact of a plowing ice sheet or iceberg. The doming of the covering reflectors and the continuation of reflectors throughout the pipes cannot be a result from a filled furrow.

\subsection{Dewatering veins and fluid-escape features}

Dewatering veins and fluid-escape features can occur on glaciated shelves in: (1) ice-proximal areas where ice becomes buried by sediment and melts later; (2) areas of rapidly deposited sediment (Collinson and Thompson, 1982; Syvitski, 1997).

Fig. 6 illustrates for each of the two settings a corresponding scheme. A conceptual model of the development of fluid-escape features as the result of buried ice and increasing sedimentary load is presented in Fig. 6a-b. During glacial times grounding ice sheets lead to a deposition of ice interbedded with subglacial debris (Fig. 6a). After the glacial retreat this ice-rock-mixture is gradually covered by glacialmarine sediments. Glacial and interglacial cycles alternate, and due to the weight of grounded ice sheets, increasing pressure of the sedimentary load and/or by warming the enclosed ice melt. Finally, the enclosed water and water-rich, fine mud are pressed out of the debris generating the observed reflection-poor structures (Fig. 6b). A further suggestion is that most of the features would have formed during times of maximum ice extent because the weight of a grounded ice sheet is much higher than the load of the overlying sediments. Applying this hypothesis to our observations in the ASE, the fluids would have had to stay frozen even during former interglacial periods until the load of grounded ice sheets and accumulated sediments caused the necessary excess of pressure. Furthermore, for formation of deeper reflection-poor structures sub-zero temperatures would have to have been maintained hundreds of metres below the sea floor. That scenario seems to be quite unrealistic because sea floor temperature could never be colder than $-2{ }^{\circ} \mathrm{C}$, and even in low geothermal gradient areas temperatures would reach positive values only $\sim 100 \mathrm{~m}$ below the sea floor.

Fig. $6 c-d$ illustrates fluid-escape veins arising from aqueous layers under the load of denser sediments. Such mud-diapirs often occur in water-rich sediments as mud and oozes. As described e.g. by Collinson and Thompson (1982) they are likely generated during rapid deposition and covering by dense layers with a low water content as caused by debris flows. Thereby loosely packed sediments with a high fraction of fine-grained material accumulate. These have a low permeability preventing pore-fluid from escaping, which in turn retards normal compaction of sediments. Finally an excess of pore-fluid pressure is produced and fluid-seeping features are generated. Fig. $5 c$ shows a seismic example of such diapirs found on the Laptev Sea continental margin by Kleiber et al. (2001). The authors described transparent sectors in subbottom profiling data and interpreted them as mud-diapirs penetrating the overlying sedimentary sequences. They suggested as origin a debris flow which caused a density inversion in the sedimentary sequences, and, due to its higher density content, pressed out the water of the underlying deposits.

Such a scenario seems most likely for the ASE. Deep troughs show that grounded ice sheets advanced onto the outer shelf in the past (Larter et al., 2007, 2009; Nitsche et al., 2007; Graham et al., 2009). Probably during and after their retreat mud-rich sediments flushed by melt-water streams were deposited on the shelf (Fig. 6c). As well, in the interglacial sediments a particularly likely kind of high-water content sediment to occur is diatom ooze, such as the one described by Hillenbrand et al. (2010) in the western ASE. Later, these water-rich deposits were buried by denser and coarse-grained sediment layers 

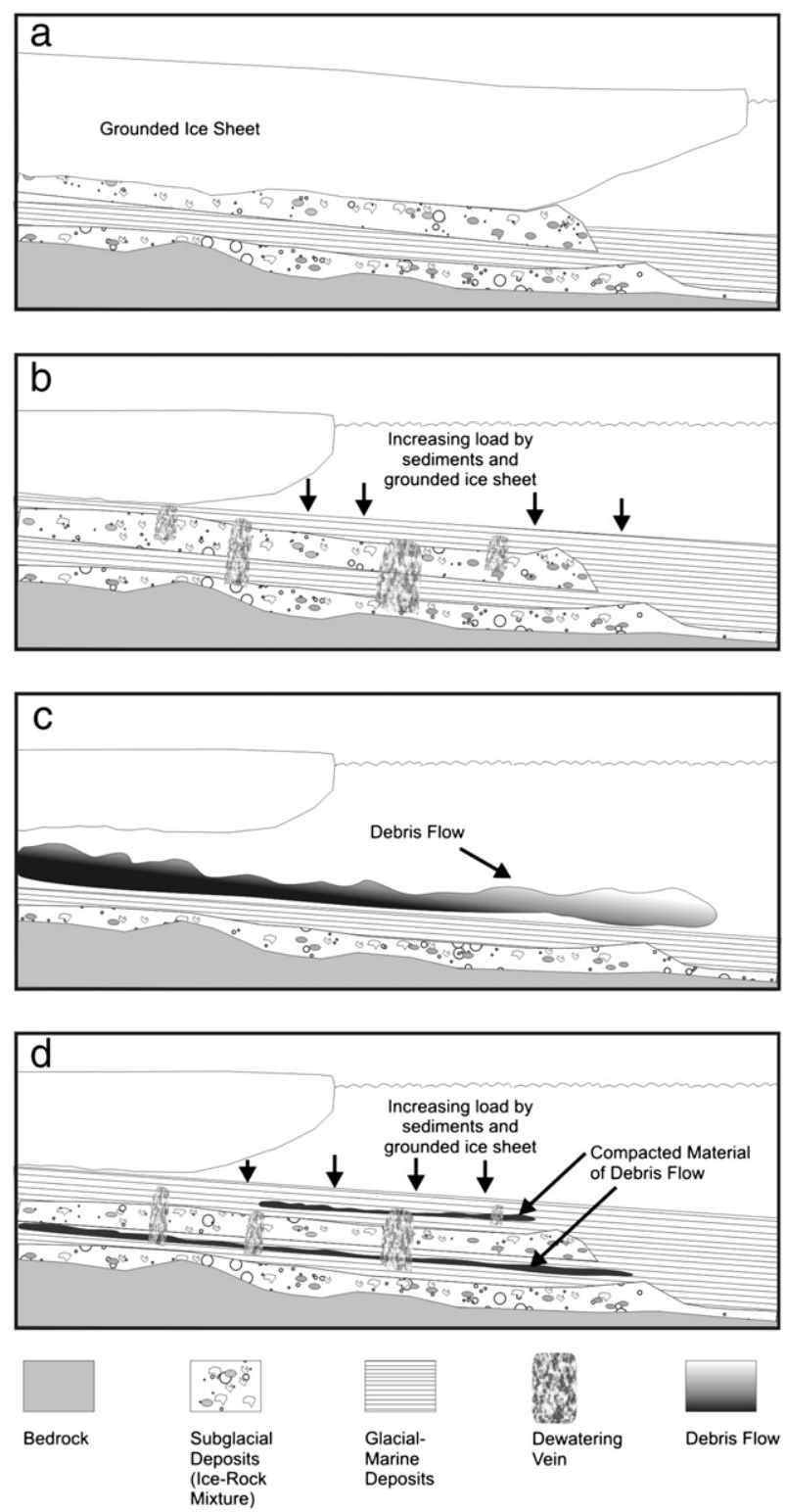

Fig. 6. Two conceptual models that illustrate how dewatering veins and water-escape features probably have been generated. Sketches a and b display a fluid-escape arising from buried ice. In (a) a grounded ice sheet advances during glacial times depositing a mixture of ice with subglacial transported debris. (b) During interglacial times glacialmarine deposits bury the glacially-derived sediments. Glacial and interglacial deposition cycles alternate and the sedimentary load increases. Finally, due to the weight of deposits and/or grounding ice sheets the enclosed ice melts and water and water-rich mud are pressed out through the sediments.Schemata $\mathrm{c}$ and $\mathrm{d}$ outline a fluid-rise caused by dense and rapidly loaded sediments. Sketch (c) shows how during interglacial times and the retreat of ice shields water-rich sediments were rapidly buried under layers with a higher density as derived e.g. from a debris flow. In (d) the dense cover prevents the water to escape until pore pressure is exceeded by the increasing sedimentary load and the enclosed fluids are pressed out. The scale of the model is selected to emphasize the relevant depositional features, thus it does not rely to any true dimensions. Any effects of sea level variations, isostasy and variations in ice thickness are not considered.

deposited quite quickly in the glacial environments - e.g. by debris flows and diamictons transported in deforming beds (e.g. Graham et al., 2010). Therefore, any layers with high water content that they bury do not have sufficient time to compact and dewater normally. Finally, the enclosed sediment slurry was pressed out through unstable zones in the sediments (Fig. 6d).

All our observed properties of the reflection-poor columns, such as the presence of reflectors below, the continuation of reflectors throughout the structures, the well-defined and upward deformed vertical flanks, and updomed top reflectors can be explained by a rising fluid. These characteristics also indicate that the structures represent post-depositional phenomena.

It is not possible to indicate an age for the reflection-poor features because there is still a lack of drilling and coring in the ASE. We also hesitate to interpret their regional distribution due to sparse seismic lines.

\section{Conclusion}

In this paper we describe peculiar reflection-poor columnar structures characterising the sedimentary sequences on the middle shelf of the ASE and discuss possibilities for their origin and nature.

The striking reflection-poor vertical features range between 50 and $500 \mathrm{~m}$ in width, and from a few metres up to $500 \mathrm{~m}$ in height. The columns originate and end in different depths, but do not reach the seafloor. Most structures are located on the middle shelf between the crest of a bathymetric high that extends NNW from Bear Peninsula and tributary troughs converging north of Martin Peninsula.

Our data unfortunately do not allow a clear conclusion on origin and genesis of these features but we exclude them to be artifacts. The described properties of the blocks most likely indicate a relatively recent ascending fluid which appears to remain as the only reasonable explanation for the reflection-poor zones.

We suggest that the structures represent mud-diapirs rising from water-rich sediments and penetrating overlying denser and coarsegrained layers. Deposits with high water content often occur close to glaciated areas. If these are covered by dense layers deposited rapidly by debris flows or by diamictons the liquids are pressed out. The observed acoustic properties of the reflection-poor blocks can be explained by a fluid pressed out from buried sedimentary layers. The presence of reflectors below the veins, the continuation of reflectors throughout the veins, the well-defined and upwards deformed vertical flanks and updomed top reflectors are consistent with a fluid rising under pressure.

In this study, we cannot unequivocally elucidate the nature of the reflection-poor zones and our interpretation on their nature might be speculative. Since these kinds of features have been described for only a few locations and their origin remains uncertain a denser net of seismic lines supported by drill cores into the reflection-poor columns is needed to unravel their secret.

\section{Acknowledgement}

We are grateful for the excellent support of Captain Pahl and his crew of RV Polarstern cruise ANT-XXIII/4. We thank G. Kuhn for providing parasound data, and J.B. Anderson and J. Wellner for providing single-channel seismic lines. F. Niessen helped with discussions on water loaded sediments and mud diapirs on glacial shelves. We thank three anonymous reviewers for their constructive comments and helpful suggestions. The Deutsche Forschungsgemeinschaft (DFG) provided funds for this research under contract number Go724/9. This is a contribution to the AWI research program PACES Topic 3 Workpackage 2.

\section{References}

Anderson, J.B., 1999. Antarctic Marine Geology. Cambridge University Press, New York. Bart, P.J., 2003. Were West Antarctic Ice Sheet grounding events in Ross Sea a consequence of East Antarctic Ice Sheet expansion during the middle Miocene? Earth and Planetary Science Letters 216, 93-107. http://dx.doi.org/10.1016/S0012-821X(03)00509-0.

Bartek, L.R., Vail, P.R., Anderson, J.B., Emmet, P.A., Wu, S., 1991. Effect of Cenozoic ice sheet fluctuations in Antarctica on the stratigraphic signature of the Neogene. Journal of Geophysical Research 96 (B4), 6753-6778.

Berndt, C., Bünz, S., Clayton, T., Mienert, J., Saunders, M., 2004. Seismic character of bottom-simulating reflections: examples from the mid-Norwegian margin. Marine and Petroleum Geology 21, 723-733.

Bohrmann, G., Kuhn, G., Abelmann, A., Gersonde, R., Fütterer, D., 1990. A young porcellanite occurrence from the southwest Indian Ridge. Marine Geology 90, 155-163.

Collinson, J.D., Thompson, D.B., 1982. Sedimentary Structures. George Allen \& Unwin, London, $194 \mathrm{pp}$.

De Santis, L., Anderson, J.B., Brancolini, G., Zayatz, I., 1995. Seismic record of late Oligocene through Miocene glaciation on the central and eastern continental shelf on the Ross 
Sea. In: Cooper, A.K., Barker, P.F., Brancolini, G. (Eds.), Geology and Seismic Stratigraphy of the Antarctic Margin. Antarctic Research Series. American Geophysical Union, Washington, DC, pp. 235-260.

Dowdeswell, J.A., Whittington, R.J., Villinger, H., 1997. Iceberg scours: records from broad and narrow-beam acoustic systems. In: Davies, T.A., et al. (Eds.), Glaciated Continental Margins - An Atlas of Acoustic Images. Chapman \& Hall, London, pp. 27-28.

Evans, J., Dowdeswell, J.A., Ò Cofaigh, C., Benham, T.J., Anderson, J.B., 2006. Extent and dynamics of the West Antarctic Ice Sheet on the outer continental shelf of Pine Island Bay during the last glaciation. Marine Geology 230, 53-72.

Gay, A., Lopez, M., Cochonat, P., Sermondadaz, G., Seranne, M., 2006. Evidences of early to late fluid migration from an upper Miocene turbiditic channel revealed by 3D seismic coupled to geochemical sampling within seafloor pockmarks, Lower Congo Basin. Marine and Petroleum Geology 23 (3), 387-399.

Geletti, R., Busetti, M., 2011. A double bottom simulating reflector in the western Ross Sea, Antarctica. Journal of Geophysical Research 116, B04101. http://dx.doi.org/ 10.1029/2010JB007864.

Gohl, K., 2007. The Expedition ANTARKTIS-XXIII/4 of the Research Vessel "Polarstern" in 2006. Berichte zur Polar- und Meeresforschung (Reports on Polar and Marine Research), 557, pp. 31-37.

Gohl, K., 2010. The expedition of the Research Vessel "Polarstern" to the Amundsen Sea, Antarctica, in 2010 (ANT-XXVI/3). Ed. by Karsten Gohl with contributions of the participants: Berichte zur Polar- und Meeresforschung (Reports on Polar and Marine Research), 617. 19-29 pp.

Graham, A.G.C., Larter, R.D., Gohl, K., Hillenbrand, C.-D., Smith, J.A., Kuhn, G., 2009. Bedform signature of a West Antarctic palaeo-ice stream reveals a multi-temporal record of flow and substrate control. Quaternary Science Reviews 28, 2774-2793. http://dx.doi.org/10.1016/j.quascirev.2009.07.003.

Graham, A.G.C., Larter, R.D., Gohl, K., Dowdeswell, J.A., Hillenbrand, C.-D., Smith, J.A Evans, J., Kuhn, G., Deen, T., 2010. Flow and retreat of the late Quaternary PineIsland-Thwaites palaeo-ice stream, West Antarctica. Journal of Geophysical Research 115, F03025. http://dx.doi.org/10.1029/2009JF001482.

Grützner, J., Mienert, J., 1999. Physical property changes as a monitor of pelagic carbonate diagenesis; an empirically derived diagenetic model for Atlantic Ocean basins. American Association of Petroleum Geologists Bulletin 83 (9), 1485-1501.

Henriet, J.P., De Mol, B., Vanneste, M., Huvenne, V., Van Rooij, D., 2001. Carbonate mound and slope failures in the Porcupine Basin: a development model involving fluid venting. In: Shannon, P.M., Haughton, P.D.W., Corcoran, D.V. (Eds.), The Petroleum Exploration of Ireland's Offshore Basins. Geological Society, London, Special Publications, 188, pp. 375-383.

Hillenbrand, C.-D., Smith, J.A., Kuhn, G., Esper, O., Gersonde, R., Larter, R.D., Maher, B., Moreton, S.G., Shimmield, T.M., Korte, M., 2010. Age assignment of diatomaceous ooze deposited in the western Amundsen Sea Embayment after the Last Glacial Maximum. Journal of Quaternary Science 25, 280-295. http://dx.doi.org/10.1002/ jqs. 1308 .

Hovland, M., Croker, P.F., Martin, M., 1994. Fault-associated seabed mounds (carbonate knolls?) off western Ireland and north-west Australia. Marine and Petroleum Geology 1 (12), 232-246.

Jakobsson, M., Anderson, J.B., Nitsche, F.O., Dowdeswell, J.A., Gyllencreutz, R., Kirchner N., Mohammad, R., O'Regan, M., Alley, R.B., Anandakrishnan, S., Eriksson, B. Kirshner, A., Fernandez, R., Stolldorf, T., Minzoni, R., Majewski, W., 2011. Geological record of ice shelf break-up and grounding line retreat, Pine Island Bay, West Antarctica. Geology 39, 691-694.

Jenkins, A., Dutrieux, P., Jacobs, S.S., McPhail, S.D., Perrett, J.R., Webb, A.T., White, D., 2010. Observations beneath Pine Island Glacier in west Antarctica and implications for its retreat. Nature Geoscience 3, 468-472. http://dx.doi.org/10.1038/ngeo890.

Jones, J.H., Segnit, E.R., 1971. Genesis of cristobalite and tridymite at low temperatures. Journal of the Geological Society of Australia 18, 419-422.

Kastner, M., Keene, J.B., Gieskes, J.M., 1977. Diagenesis of siliceous oozes-I. Chemica controls on the rate of opal-A to opal-CT transformation an experimental study. Geochimica et Cosmochimica Acta 41, 1041-1059.

Kleiber, H.P., Niessen, F., Weiel, D., 2001. The late Quaternary evolution of the western Laptev Sea continental margin, Arctic Siberia - implications from sub-bottom profiling. Global and Planetary Change 31, 105-124.

Kuijpers, A., Dalhoff, F., Brandt, M.P., Hümbs, P., Schott, T., Zotova, A., 2007. Giant iceberg plow marks at more than $1 \mathrm{~km}$ water depth offshore West Greenland. Marine Geology 246, 60-64. http://dx.doi.org/10.1016/j.margeo.2007.05.010.

Kvenvolden, K.A., Golan-Bac, M., Rapp, J.B., 1987. Hydrocarbon geochemistry of sediments offshore Antarctica, I. Wilkes Land continental margin. The Antarctic Continental Margin: Geology and Geophysics Offshore Wilkes Land and the Western Ross Sea: Circum-Pacific Council on Energy and Mineral Resources, Earth Science Series, 5A, pp. 205-213.

Larter, R., 2008. Antarctic Peninsula. In: Cooper, A.K., G. Brancolini, C. Escutia, Y. Kristoffersen, R. Larter, G. Leitchenkov, P. O'Brien, W. Jokat, Cenozoic climate history from seismicreflection and drilling studies on the Antarctic continental margin. In: Florindo, F., Siegert, M. (Eds.), Antarctic Climate Evolution, Developments in Earth and Environmental Sciences, Vol. 8, Elsevier, 537 pp.

Larter, R., Gohl, K., Hillenbrand, C.D., Kuhn, G., Deen, T.J., Dietrich, R., Eagles, G., Johnson, J.S., Livermore, R.A., Nitsche, F.O., Pudsey, C.J., Schenke, H.-W., Smith J.A., Udintsev, G., Uenzelmann-Neben, G., 2007. West Antarctic Ice Sheet change since the last glacial period. EOS, Transactions, American Geophysical Union 88, 189-196.

Larter, R.D., Graham, A.G.C., Gohl, K., Kuhn, G., Hillenbrand, C.-D., Smith, J.A., Deen, T.J., Livermore, R., Schenke, H.-W., 2009. Subglacial bedforms reveal complex basal regime in a zone of paleo-ice stream convergence, Amundsen Sea Embayment, West Antarctica. Geology 37, 411-414. http://dx.doi.org/10.1130/G25505A.
Lee, G.H., Kwon, Y.I., Yoon, C.S., Kim, H.J., Yoo, H.S., 2006. Igneous complexes in the eastern Northern South Yellow Sea Basin and their implications for hydrocarbon systems. Marine and Petroleum Geology 23, 631-645.

Long, D., Praeg, D., 1997. Buried ice-scours: 2D vs 3D-seismic geomorphology. In: Davies, T.A., et al. (Eds.), Glaciated Continental Margins - An Atlas of Acoustic Images. Chapman \& Hall, London, pp. 142-143.

Lowe, A.L., Anderson, J.B., 2002. Reconstruction of the West Antarctic ice sheet in Pine Island Bay during the Last Glacial Maximum and its subsequent retreat history. Quaternary Science Reviews 21, 1879-1897.

Mann, R., Gieskes, J., 1975. Interstitial water studies, Leg 28. Initial Reports: Deep Sea Drilling Project, 28, pp. 805-817.

Mclver, R.D., 1975. Hydrocarbon gases in canned core samples from Leg 28 sites 271, 272, and 273, Ross Sea. Initial Reports: Deep Sea Drilling Project, 28, pp. 815-817.

Moss, J.L., Cartwright, J., 2010. 3D seismic expression of km-scale fluid escape pipes from offshore Namibia. Basin Research 22, 481-501. http://dx.doi.org/10.1111/ j.1365-2117.2010.00461.x.

Neurauter, T., Bryant, W., 1990. Seismic expression of sedimentary volcanism on the continental slope northern Gulf of Mexico. Geo-Marine Letters 10 (4), 225-231.

Nitsche, F.O., Cunningham, A.P., Larter, R.D., Gohl, K., 2000. Geometry and development of glacial continental margin depositional systems in the Bellingshausen Sea. Marine Geology 162, 277-302.

Nitsche, F.O., Jacobs, S., Larter, R.D., Gohl, K., 2007. Bathymetry of the Amundsen Sea Continental Shelf: implications for geology, oceanography, and glaciology. Geochemistry Geophysics Geosystems (G3) 8 (10), Q10009. http://dx.doi.org/10.1029/ 2007GC001694.

Pecher, I.A., Minshull, T.A., Singh, S.C., von Huene, R., 1996. Velocity structure of a bottom simulating reflector offshore Peru. Earth and Planetary Science Letters 139, 459-469.

Petersen, C.J., Papenberg, C., Klaeschen, D., 2007. Local seismic quantification of gas hydrates and BSR characterization from multi-frequency OBS data at northern Hydrate Ridge. Earth and Planetary Science Letters 255 (3-4), 414-431.

Post, A.L., O'Brien, P.E., Beaman, R.J., Riddle, M.J., De Santis, L., 2010. Physical controls on deep water coral communities on the George V Land slope, East Antarctica. Antarctic Science 22 (4), 371-378. http://dx.doi.org/10.1017/S0954102010000180.

Pritchard, H.D., Arthern, R.J., Vaughan, D.G., Edwards, L.A., 2009. Extensive dynamic tinning on the margins of the Greenland and Antarctic Ice Sheets. Nature 461, 971-975. http://dx.doi.org/10.1038/nature08471.

Riech, V., Von Rad, U., 1979. Silica diagenesis in the Atlantic Ocean: diagenetic potential and transformations. In: Talwani, M., et al. (Ed.), Deep Drilling Results in the Atlantic Ocean: Continental Margins and Paleoenvironments. M. Ewing Ser., 3. American Geophysical Union, Washington, pp. 315-340.

Rignot, E., 2008. Changes in West Antarctic ice stream dynamics observed with ALOS PALSAR data. Geophysical Research Letters 35, L12505. http://dx.doi.org/10.1029/ 2008GL033365.

Rignot, E., Jacobs, S.S., 2002. Rapid bottom melting widespread near Antarctic ice sheet grounding lines. Science 296, 2020-2023.

Sager, W.W., MacDonald, I.R., Hou, R., 2003. Geophysical signatures of mud mounds at hydrocarbon seeps on the Louisiana continental slope, northern Gulf of Mexico. Marine Geology 19 (1-2), 97-132.

Sain, K., Minshull, T.A., Singh, S.C., Hobbs, R.W., 2000. Evidence for a thick free gas layer beneath the bottom-simulating reflector in the Makran accretionary prism. Marine Geology 164 (1-2), 3-12.

Scheuer, C., Gohl, K., Larter, R.D., Rebesco, M., Udintsev, G., 2006. Variability in Cenozoic sedimentation along the continental rise of the Bellingshausen Sea, West Antarctica. Marine Geology 277, 279-298. http://dx.doi.org/10.1016/j.margeo.2005.12.007.

Scott, J.B.T., Gudmundsson, G.H., Smith, A.M., Bingham, R.G., Pritchard, H.D., Vaughan, D.G., 2009. Increased rate of acceleration on Pine Island Glacier strongly coupled to changes in gravitational driving stress. The Cryosphere 3, 125-131.

Shepherd, A., Wingham, D., Rignot, E., 2004. Warm ocean is eroding West Antarctic ice sheet. Geophysical Research Letters 31, L23402. http://dx.doi.org/10.1029/ 2004GL021106.

Shipley, T.H., Huston, M.H., Buffer, R.T., Shaub, F.J., McMillen, K.J., Ladd, J.W., Worzel, J.L., 1979. Seismic evidence for widespread possible gas hydrate horizons on continental slopes and rises. American Association of Petroleum Geologists Bulletin 63, 2204-2213.

Sloan, E.D., 1998. Gas hydrates: review of physical/chemical properties. Energy \& Fuels $12,191-196$

Smith, J.A., Hillenbrand, C.-D., Kuhn, G., Larter, R.D., Graham, A.G.C., Ehrmann, W., Moreton, S.G., Forwick, M., 2011. Deglacial history of the West Antarctic Ice Sheet in the western Amundsen Sea Embayment. Quaternary Science Reviews 30 (5-6), 488-505.

Stoker, M.S., 1997. Glacimarine environments/geomorphic provinces: overview. In: Davies, T.A., et al. (Eds.), Glaciated Continental Margins - An Atlas of Acoustic Images. Chapman \& Hall, London, pp. 169-171.

Syvitski, J.P., 1997. Water-escape sea floor depressions. In: Davies, T.A., et al. (Eds.), Glaciated Continental Margins - An Atlas of Acoustic Images. Chapman \& Hall, London, pp. 160-161.

Ten Brink, U.S., Schneider, C., Johnson, A.H., 1995. Morphology and stratal geometry of the Antarctic continental shelf: insights from models. In: Cooper, A.K., Barker, P.F., Brancolini, G. (Eds.), Geology and Seismic Stratigraphy of the Antarctic Margin. Antarctic Research Series, 68. AGU, Washington, D.C., pp. 1-24.

Tingdahl, K.M., Bril, A.H., de Groot, P.F., 2001. Improving seismic chimney detection using directional attributes. Journal of Petroleum Science and Engineering 29 (3-4), 205-211.

Tribble, J.S., MacKenzie, F.T., Urmos, J., O`Brien, D.K., Manghnani, M.H., 1992. Effects of biogenic silica on acoustic and physical properties of clay-rich marine sediments. American Association of Petroleum Geologists Bulletin 76 (6), 792-804 
Uenzelmann-Neben, G., Gohl, K., Larter, R.D., Schlüter, P., 2007. Differences in ice retreat across Pine Island Bay, West Antarctica, since the Last Glacial Maximum: indications from multichannel seismic reflection data. In: Cooper, A.K., Raymond, C.R., et al. (Eds.), A Keystone in a Changing World-Online Proceedings of the 10th ISAES, USGS Open-File Report 2007-1047: Short Research Paper, 084. http://dx.doi.org/ 10.3133/of2007-1047.srp084.

Vaughan, D.G., Corr, H.F.J., Smith, A.M., Jenkins, A., Bentley, C.R., Stenoien, M.D., Jacobs, S.S., Kellogg, T.B., Rignot, E., Lucchitta, B.K., 2001. A review of ice sheet dynamics in the Pine Island Glacier basin, West Antarctica: hypotheses of instability vs. observations of change. In: Alley, R.B., Bindschadler, R.A. (Eds.), The West Antarctic Ice Sheet: Behavior and Environment. American Geophysical Union, Washington DC, pp. 237-256.
Volpi, V., Camerlenghi, A., Hillenbrand, C.-D., Rebesco, M., Ivaldi, R., 2003. Effects of biogenic silica on sediment compaction and slope stability on the Pacific margin of the Antarctic Peninsula. Basin Research 15 (3), 339-363.

Weigelt, E., Gohl, K., Uenzelmann-Neben, G., Larter, R.D., 2009. Late Cenozoic ice sheet cyclicity in the western Amundsen Sea Embayment - evidence from seismic records. Global and Planetary Change 69, 162-169. http://dx.doi.org/10.1016/ j.gloplacha.2009.07.004.

Yilmaz, Ö., 2001. Seismic data analysis. Investigations in Geophysics, 10. Society of Exploration Geophysicists, Tulsa, p. 2027. 